\title{
QUARTERLY OUTLOOK ON \\ MONETARY, BANKING, AND PAYMENT SYSTEM IN INDONESIA: QUARTER IV-2015
}

\author{
TM. Arief Machmud, Syachman Perdymer, Muslimin Anwar, \\ Nurkholisoh Ibnu Aman, Tri Kurnia Ayu K, \\ Anggita Cinditya Mutiara K, Illinia Ayudhia Riyadi ${ }^{1}$
}

\begin{abstract}
Indonesia 's economy in the fourth quarter 2015 was marked by maintained macroeconomic and financial system stability, with a starting economic growth momentum. Macroeconomic stability reflected by lower inflationary pressures, a current account deficit in a healthy level, and manageable pressure on Rupiah. The stability of the financial system remains solid, underpinned by the resilience of the banking system and the relatively stong financial market performance. As the third quarter of 2015, economic growth in the fourth quarter 2015 increased mainly driven by government spending. Looking ahead, economic growth is expected to be higher, with the support of fiscal stimulus, particularly a faster implementation of infrastructure projects, and also with the increase of private investment.
\end{abstract}

Keywords: macroeconomy, monetary, economic outlook.

JEL Classification: C53, E66, F01, F41

1 Authors are researcher on Monetary and Economic Policy Department (DKEM). TM_Arief Machmud (tm_arief@bi.go.id); Syachman Perdymer (syachman@bi.go.id); Muslimin AAnwar (imus@bi.go.id); Nurkholisoh Ibñu Aman (nurkholisoh@bi.go.id); Tri Kurnia Ayu K (tri_kas@bi.go.id); Anggita Cinditya Mutiara K (anggita_cmk@bi.go.id); Illinia Ayudhia Riyadi (illinia_ar@bi.go.id). 


\section{PERKEMBANGAN GLOBAL}

Pemulihan ekonomi global berisiko untuk terus melemah. Sementara itu, risiko di pasar keuangan global yang bersumber dari kemungkinan kenaikan Suku Bunga Kebijakan Bank Sentral Amerika Serikat (AS) atau Fed Fund Rate (FFR), semakin mereda. Pemulihan ekonomi AS masih tertahan seiring dengan konsumsi yang masih lemah, perbaikan sektor perumahan yang melambat dan sektor manufaktur yang masih terkontraksi. Pemulihan ekonomi AS yang belum solid mengakibatkan perkiraan kenaikan FFR bergeser mundur pada semester II 2016 dengan besaran kenaikan yang lebih rendah. Bank Sentral Eropa (ECB) masih melanjutkan kebijakan quantitave easing (QE) sejalan dengan pertumbuhan ekonomi dan inflasi Eropa yang masih rendah. Demikian pula Bank Sentral Jepang yang mulai menerapkan kebijakan suku bunga negatif. Di sisi lain, perekonomian Tiongkok terus melambat akibat masih lemahnya sektor manufaktur dan investasi, sejalan dengan proses deleveraging yang dilakukan oleh sektor korporasi. Sementara itu, di pasar komoditas harga minyak dunia diperkirakan cenderung menurun, akibat meningkatnya supply dan melemahnya permintaan.

Risiko di pasar keuangan global yang terkait kenaikan Suku Bunga Kebijakan Bank Sentral Amerika Serikat (AS) atau FFR, semakin mereda. Hal itu terindikasi dari menurunnya indeks VIX spot dan membaiknya pasar saham AS paska FOMC Januari 2016 (Grafik 1 dan 2). Ke depan, persepsi risiko diperkirakan menurun, tercermin dari VIX Future pada Juni 2016 yang lebih rendah dibandingkan VIX spot.

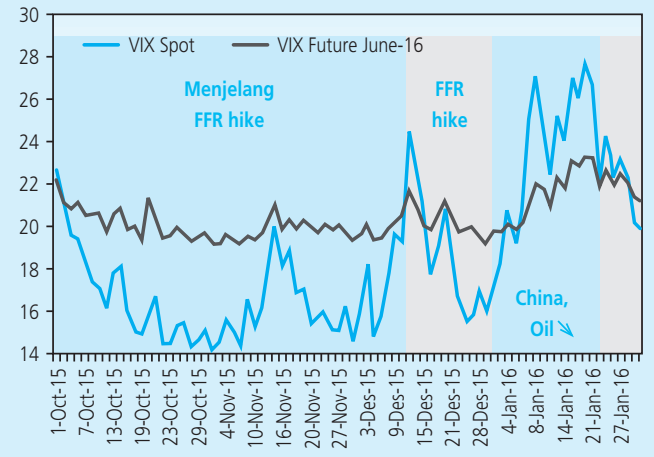

Grafik 1.

Perkembangan Indeks VIX: Spot dan Forward

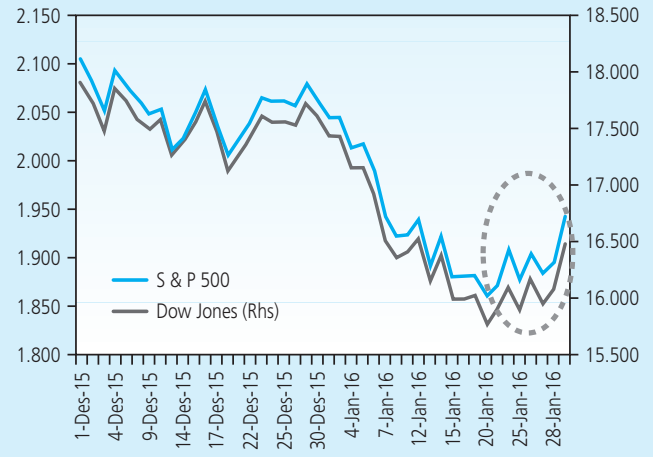

Grafik 2.

Perkembangan Indeks Bursa Saham AS

Pemulihan ekonomi AS masih tertahan seiring dengan konsumsi yang masih lemah, perbaikan sektor perumahan yang melambat dan sektor manufaktur yang masih terkontraksi. Masih lemahnya konsumsi AS tercermin dari pertumbuhan penjualan ritel dan personal 
expenditure yang masih lemah. Perbaikan sektor perumahan melambat, terlihat dari pertumbuhan penjualan rumah dalam tren menurun meski suku bunga KPR cenderung turun. Sementara itu, sektor manufaktur juga masih terkontraksi, terindikasi dari PMI Manufaktur, industrial production, dan kapasitas produksi yang terus menurun. Dari sisi inflasi, inflasi (PCE) masih jauh di bawah target.

Pemulihan ekonomi AS yang belum solid mengakibatkan perkiraan kenaikan FFR bergeser mundur pada semester II 2016 dengan besaran kenaikan yang lebih rendah. FOMC Januari 2016 dan testimoni Yellen di depan kongres (10 Februari 2016) mengindikasikan bahwa kenaikan FFR akan dilakukan secara gradual dengan mempertimbangkan risiko ekonomi dan pasar keuangan global yang dapat mempengaruhi prospek perbaikan AS. Berdasarkan survei Bloomberg terkini (73 ekonom), kenaikan FFR diperkirakan hanya sebesar 50 bps pada 2016, lebih rendah dibandingkan survei bulan Januari 2016 sebesar 75 bps. Bahkan, pasar futures (FFR Implied Probability) memperkirakan tidak terjadi kenaikan FFR selama 2016.

Bank Sentral Eropa (ECB) masih melanjutkan kebijakan quantitave easing (QE) sejalan dengan pertumbuhan ekonomi dan inflasi Eropa yang masih rendah. ECB diperkirakan melakukan penambahan QE pada bulan Maret 2016. Hal itu sejalan dengan hasil Governing Council (GC) Meeting pada Desember 2015 yang memperkirakan tingkat yang masih rendah inflasi (Grafik 3), dipengaruhi oleh menurunnya harga minyak dan komoditas yang menurun. Inflasi Eropa pada Desember 2015 tercatat sebesar 0,2\%, di bawah ekspektasi. Selain itu, terdapat risiko euro terapresiasi dan menurunnya tingkat keyakinan pelaku pasar terhadap ECB dalam mengarahkan inflasi ke target.

Demikian pula, Bank Sentral Jepang juga mulai menerapkan kebijakan suku bunga negatif. Hal ini dilakukan sebagai respons terhadap turunnya ekspektasi inflasi. Penurunan inflasi Jepang utamanya berasal dari turunnya harga impor, terutama impor bahan energi dan bahan makanan. Penerapan suku bunga negatif berlaku bagi sebagian reserves baru yang ditempatkan di Bank Sentral Jepang. Tujuan dari penerapan kebijakan ini adalah menurunkan tingkat suku bunga riil, sehingga diharapkan dapat mendorong investasi dan konsumsi.

Di sisi lain, perekonomian Tiongkok terus melambat akibat masih lemahnya sektor manufaktur dan investasi, sejalan dengan proses deleveraging yang dilakukan oleh sektor korporasi. Lemahnya sektor manufaktur terindikasi dari penurunan pertumbuhan industrial production dan PMI yang masih terus berlangsung (Grafik 4). Selain itu, investasi juga masih lemah, tercermin dari menurunnya fixed asset investment (FAI). Melambatnya perekonomian Tiongkok sejalan dengan proses deleveraging yang dilakukan oleh sektor korporasi. 


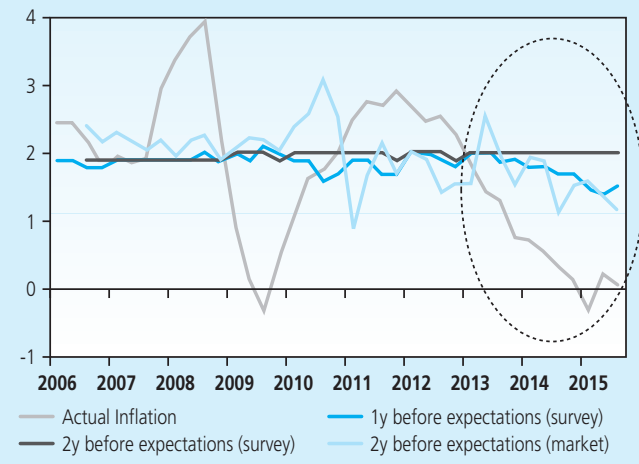

Grafik 3.

Perkembangan Tingkat Inflasi Eropa

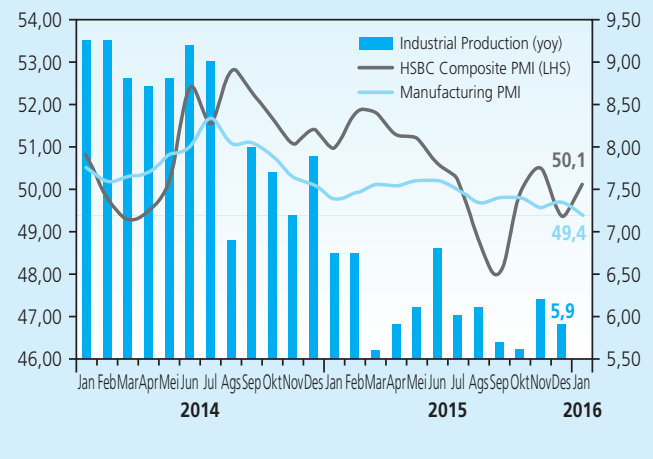

Grafik 4. Industrial Production dan PMI Tiongkok

Terkait dengan pergerakan yuan (renminbi), yuan masih berisiko melemah dan volatile, dengan mempertimbangkan risiko fundamental serta ketidakpastian kebijakan nilai tukar dan aturan di pasar saham Tiongkok. Pasca devaluasi Agustus 2015, CNY sudah mendekati fixing CNY. Namun, level tersebut masih overvalued, tercermin dari spread CNY dan CNH yang lebar. Selain itu, terjadi over-pricing saham di bursa saham Tiongkok. Risiko ini dapat memicu kembali capital outflows. Interevensi di pasar valas tidak dapat terus ditempuh mengingat posisi cadev yg hampir berada di bawah standard metric IMF.

Di pasar komoditas, harga minyak dunia diperkirakan cenderung menurun, seiring meningkatnya supply dan melemahnya permintaan. Harga minyak 2015 turun 47 persen dibandingkan 2014, dan berlanjut di awal 2016 hingga mencapai titik terendah 26,4 dolar AS per barel (Grafik 5). Meningkatnya supply didorong oleh pasokan OPEC pada akhir 2015 yang meningkat akibat Irak dan Arab Saudi yang mempertahankan pangsa pasarnya (Grafik 6). Sementara itu, menurunnya permintaan terjadi akibat ekonomi global yang diperkirakan masih lemah.

Penurunan harga minyak memberi tekanan ke harga komoditas lainnya, di samping pelemahan ekonomi Tiongkok dan peralihan strategi investasi ke pasar uang. Harga minyak berkorelasi positif dengan harga komoditas lainnya. Penurunan harga komoditas nonmigas juga terjadi karena adanya shifting investasi dari komoditas (asset class) ke aset USD, sejalan dengan ekspektasi normalisasi kebijakan moneter AS. 


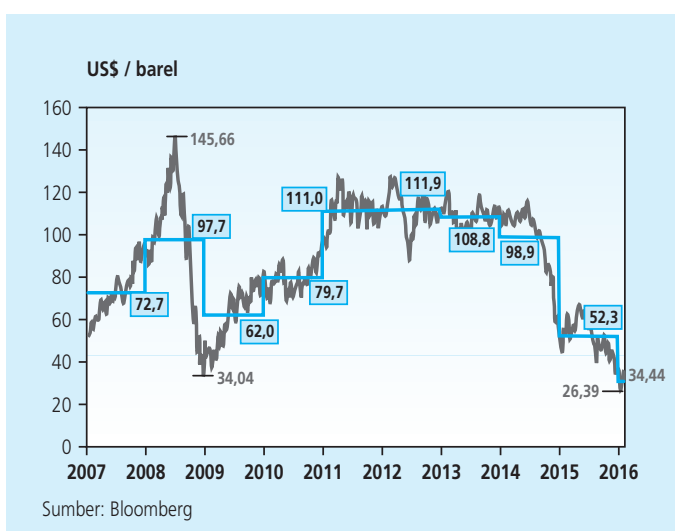

Grafik 5. Perkembangan Harga Minyak Brent (per 15 Februari 2016)

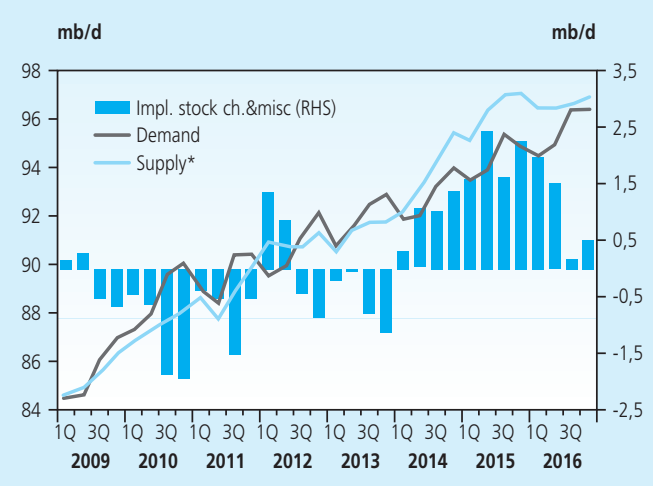

Grafik 6. Perkembangan Permintaan dan Penawaran Minyak Dunia

\section{DINAMIKA MAKROEKONOMI INDONESIA}

\subsection{Pertumbuhan Ekonomi}

Momentum pertumbuhan ekonomi Indonesia yang mulai terjadi sejak triwulan III 2015, berlanjut ke triwulan IV 2015, antara lain didorong oleh pengeluaran pemerintah. Pertumbuhan ekonomi triwulan IV 2015 tercatat 5,04\% (yoy), lebih tinggi dari triwulan sebelumnya sebesar 4,74\% (yoy) (Tabel 1). Peningkatan pertumbuhan ekonomi pada triwulan IV 2015 antara lain didorong oleh peran pemerintah, baik dalam bentuk konsumsi pemerintah maupun investasi infrastruktur, serta penyelenggaraan Pilkada. Di sisi lain, peran sektor swasta masih terbatas, yang tercermin dari konsumsi rumah tangga dan investasi nonbangunan yang belum kuat. Dari sisi eksternal, ekspor masih menurun seiring pemulihan ekonomi global yang berjalan lambat dan harga komoditas yang terus turun. Secara sektoral, pertumbuhan ekonomi juga belum merata dan lebih ditopang oleh sektor konstruksi terkait infrastruktur serta sektor jasa.

\begin{tabular}{|c|c|c|c|c|c|c|}
\hline \multicolumn{7}{|c|}{$\begin{array}{c}\text { Table } 1 \\
\text { Pertumbuhan Ekonomi Sisi Pengeluaran (\%, yoy) }\end{array}$} \\
\hline \multirow{2}{*}{ Komponen } & \multirow{2}{*}{2014} & \multicolumn{4}{|c|}{2015} & \multirow{2}{*}{2015} \\
\hline & & I & II & III & IV & \\
\hline Konsumsi Rumah Tangga* & 5.29 & 4.72 & 4.68 & 4.98 & 4.99 & 4.84 \\
\hline Konsumsi Pemerintah & 1.16 & 2.91 & 2.61 & 7.11 & 7.31 & 5.38 \\
\hline Investasi & 4.57 & 4.63 & 3.88 & 4.79 & 6.90 & 5.07 \\
\hline Investasi Bangunan & 5.52 & 5.47 & 4.82 & 6.25 & 8.21 & 6.23 \\
\hline Investasi NonBangunan & 2.03 & 2.35 & 1.32 & 0.73 & 3.10 & 1.87 \\
\hline Ekspor Barang dan Jasa & 1.00 & -0.62 & -0.01 & -0.60 & -6.44 & -1.97 \\
\hline Impor Barang dan Jasa & 2.19 & -2.19 & -6.97 & -5.90 & -8.05 & -5.84 \\
\hline PDB & 5.02 & 4.73 & 4.66 & 4.74 & 5.04 & 4.79 \\
\hline
\end{tabular}


Konsumsi pemerintah pada triwulan IV 2015 tumbuh 7,31\% (yoy), meningkat dari 7,11\% (yoy) pada triwulan sebelumnya. Peningkatan tersebut terutama disebabkan oleh penyerapan belanja barang yang lebih tinggi. Perkembangan ini menunjukkan peran pemerintah yang semakin kuat dalam mendorong ekonomi, meskipun di awal tahun belanja pemerintah sempat terkendala oleh penyesuaian nomenklatur.

Pertumbuhan investasi, khususnya investasi bangunan, juga meningkat sehingga mampu menopang pertumbuhan ekonomi triwulan IV 2015. Secara keseluruhan, investasi tumbuh meningkat menjadi 6,90\% (yoy), dari 4,79\% (yoy) pada triwulan III 2015. Peningkatan tersebut terutama didorong oleh investasi bangunan yang tumbuh tinggi sejalan dengan akselerasi proyek infrastruktur pemerintah. Hal itu tercermin dari indikator investasi bangunan, seperti penjualan semen yang membaik. Sementara itu, peran sektor swasta masih terbatas tercermin dari pertumbuhan investasi nonbangunan yang belum kuat pada triwulan IV 2015 (3,1\%). Hal ini didorong oleh perilaku wait and see investor, sebagaimana terlihat pada sentimen bisnis yang belum membaik. Kinerja dan daya tahan korporasi juga mengalami penurunan. Pada tahun 2015, pendapatan korporasi dari hasil penjualan mengalami pertumbuhan negatif (Grafik 7). Meskipun belum kuat, investasi nonbangunan tumbuh membaik, didorong oleh positifnya kinerja investasi mesin dan perlengkapan, kendaraan dan peralatan, serta meningkatnya impor barang modal.

Pertumbuhan konsumsi swasta pada triwulan IV 2015 sedikit meningkat, terutama didorong oleh peningkatan konsumsi Lembaga Non Profit Rumah Tangga (LNPRT). Pertumbuhan konsumsi rumah tangga pada triwulan IV 2015 sedikit meningkat dari 4,98\% (yoy) pada triwulan III 2015 menjadi 4,99\% (yoy), terutama didorong oleh meningkatnya konsumsi Lembaga Non Profit Rumah Tangga (LNPRT). Pertumbuhan konsumsi LNPRT meningkat dari 6,56\% (yoy) menjadi 8,32\% (yoy), sejalan dengan peningkatan aktivitas Pilkada pada triwulan IV 2015.

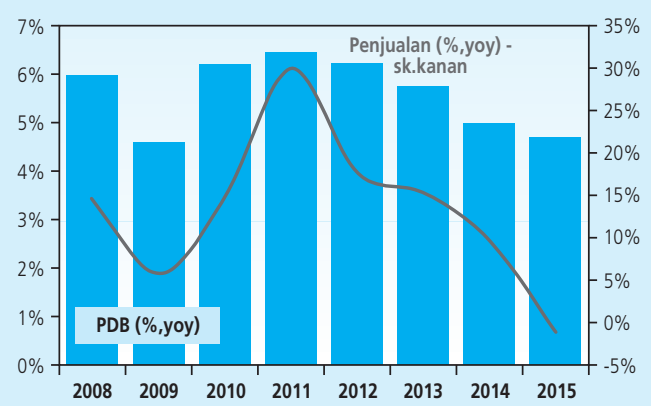

Grafik 7. Pendapatan Penjualan Korporasi

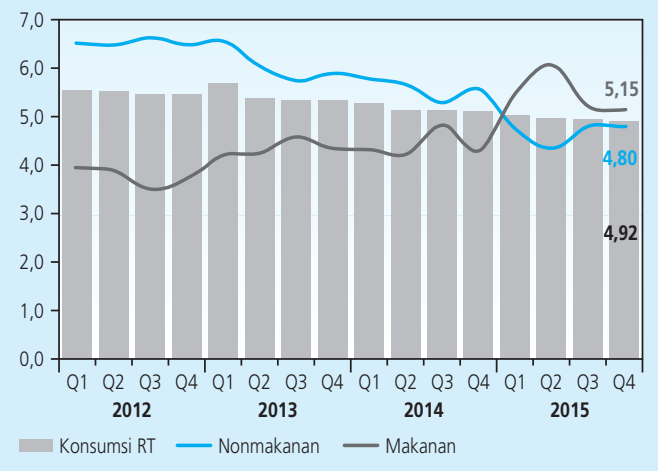

Grafik 8. Pertumbuhan Konsumsi Rumah Tangga 
Terbatasnya konsumsi rumah tangga terindikasi dari perbaikan konsumsi nonmakanan yang belum kuat (Grafik 8). Selain itu, indikator penjualan mobil dan motor masih mencatat kontraksi, meskipun penjualan motor menunjukkan perbaikan pada Desember 2015. Kredit konsumsi, yang dapat mendorong daya beli masyarakat, juga masih menunjukkan tren perlambatan.

Di sisi eksternal, ekspor masih menurun seiring pemulihan ekonomi global yang berjalan lambat dan harga komoditas yang terus turun. Ekspor pada triwulan IV 2015 mencatat kontraksi 6,44\% (yoy), lebih besar dibandingkan kontraksi pada triwulan sebelumnya. Pelemahan tersebut terkait dengan perlambatan volume perdagangan dunia, terutama ke emerging countries, dan harga komoditas yang cenderung lebih rendah sejalan dengan penurunan harga minyak dunia. Berdasarkan kelompoknya, penurunan ekspor terutama didorong oleh pelemahan ekspor nonmigas. Ekspor tambang masih terkontraksi, terutama ekspor batubara sejalan dengan harga yang rendah dan permintaan yang melemah, khususnya dari Tiongkok. Ekspor manufaktur sedikit terkontraksi, seiring terkontraksinya ekspor CPO setelah tumbuh positif di tiga triwulan sebelumnya. Sementara itu, ekspor pertanian tumbuh positif khususnya ekspor ikan, biji kopi, dan rempah-rempah.

Kontraksi impor kembali meningkat, merespons penurunan kinerja ekspor dan konsumsi yang terbatas. Impor mengalami kontraksi sebesar 8,05\% (yoy) pada triwulan IV 2015, lebih besar dibandingkan triwulan sebelumnya yang terkontraksi sebesar 5,90\% (yoy). Kontraksi impor tersebut terutama disebabkan oleh kontraksi impor migas, di tengah berlanjutnya kontraksi impor nonmigas yang sedikit tertahan. Tertahannya kontraksi impor nonmigas tersebut didorong oleh perbaikan tajam impor barang modal, sejalan dengan mulai berjalannya proyek infrastruktur pemerintah di 2015.

Secara sektoral (lapangan usaha), kenaikan pertumbuhan ekonomi belum merata. Kenaikan pertumbuhan terutama ditopang oleh sektor konstruksi terkait proyek infrastruktur dan sektor jasa, sementara lapangan usaha lain, termasuk manufaktur, belum tumbuh kuat. Kinerja sektor kontruksi tumbuh menguat didorong oleh akselerasi pembangunan proyek infrastruktur pemerintah. Dari sektor jasa, peningkatan antara lain didorong oleh subsektor administrasi pemerintah sejalan dengan belanja pemerintah yang meningkat dan subsektor jasa keuangan. Sementara itu, sektor manufaktur masih melambat, sejalan dengan kecenderungan melemahnya konsumsi swasta dan melambatnya ekspor manufaktur di penghujung tahun. Perlambatan tersebut dikonfirmasi oleh perkembangan Purchasing Manager Index (PMI) HSBC yang masih pada teritori kontraksi. Dilihat dari jenis industri, penurunan kinerja industri terutama terjadi di industri kimia, terkait dengan permintaan ekspor yang menurun. Namun, peningkatan kinerja industri pengilangan migas yang cukup kuat mampu meredam pemburukan kinerja industri pengolahan yang lebih dalam.

Secara spasial, perbaikan ekonomi terutama didorong oleh Jawa dan Sumatera. Pertumbuhan ekonomi Jawa membaik dari 5,5\% (yoy) pada triwulan III 2015 menjadi 5,9\% (yoy) di triwulan IV 2015 (Gambar 1). Hal itu didorong oleh realisasi percepatan proyek infrastruktur 
pemerintah berskala besar seperti pembangunan waduk, pelabuhan, bandara, dan transportasi massal. Demikian halnya perekonomian Sumatera yang tumbuh meningkat dari 3,1\% (yoy) pada triwulan III 2015 menjadi 4,6\% pada triwulan IV 2015. Peningkatan ini didorong oleh realisasi proyek infrastruktur, seperti pembangunan tol, pembangkit listrik, dan berbagai sarana penunjang ASEAN Games 2018. Sementara itu, perekonomian Kalimantan masih tumbuh pada kisaran yang cukup rendah sebesar 1,5\% (yoy) dari 0,4\% (yoy) pada triwulan III 2015. Kondisi tersebut disebabkan masih lemahnya kinerja ekspor dan cenderung turunnya produksi migas khususnya di Kalimantan Timur. Di sisi lain, perekonomian Kawasan Timur Indonesia (KTI) tumbuh sedikit melambat, walaupun masih berada pada level yang cukup tinggi. Pertumbuhan KTI melambat dari 8,9\% (yoy) pada triwulan III 2015 menjadi 8,6\% di triwulan IV 2015. Hal ini dipengaruhi oleh kinerja ekspor, khususnya barang tambang, yang masih terbatas karena masih rendahnya harga komoditas.

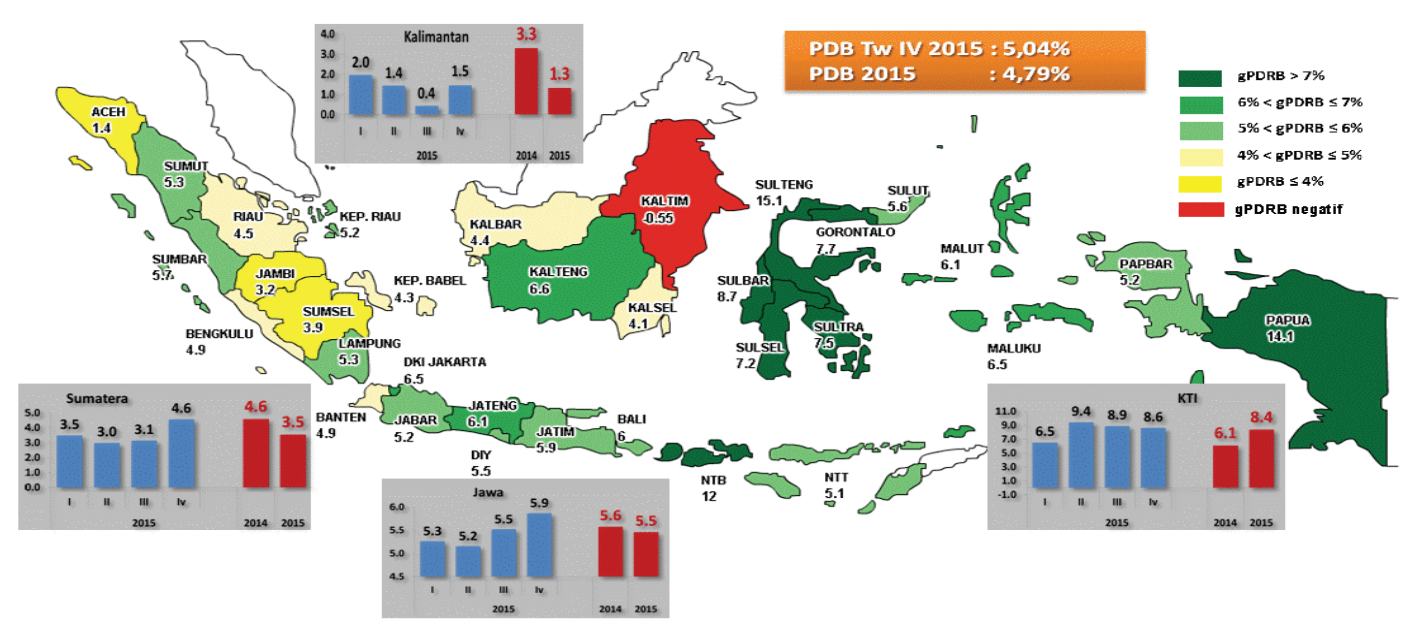

Gambar 1. Peta Pertumbuhan Ekonomi Daerah Triwulan IV 2015

\subsection{Neraca Pembayaran Indonesia}

Defisit transaksi berjalan meningkat di tengah proses perbaikan perekonomian Indonesia dan masih lemahnya permintaan global. Defisit transaksi berjalan triwulan IV 2015 tercatat sebesar 2,4\% PDB, lebih besar dibandingkan dengan triwulan sebelumnya sebesar 1,94\% PDB. Kenaikan defisit transaksi berjalan tersebut bersumber dari penurunan surplus neraca perdagangan nonmigas, karena impor nonmigas tumbuh 7,5\% (qtq) seiring dengan meningkatnya permintaan domestik pada triwulan IV 2015. Peningkatan impor terbesar terjadi pada kelompok barang modal, diikuti oleh kelompok barang konsumsi dan bahan baku. Sementara itu, ekspor nonmigas terkontraksi 4,2\% (qtq) dipengaruhi oleh permintaan global yang masih lemah dan terus menurunnya harga komoditas. Di sisi lain, defisit neraca 
perdagangan migas menyusut seiring turunnya volume impor minyak dan harga minyak mentah dunia.

Sementara itu, surplus transaksi modal dan finansial meningkat signifikan seiring menurunnya ketidakpastian di pasar keuangan global dan membaiknya keyakinan terhadap prospek perekonomian Indonesia. Surplus transaksi modal dan finansial triwulan IV 2015 sebesar 9,52 miliar dolar AS, lebih tinggi dari triwulan sebelumnya sebesar 0,28 miliar dolar AS. Kenaikan surplus transaksi modal dan finansial tersebut terutama didukung oleh kembali meningkatnya arus masuk investasi portofolio pada obligasi pemerintah, termasuk global bond. Selain itu, kenaikan surplus transaksi modal finansial didukung pula oleh kenaikan investasi lainnya dan aliran masuk investasi langsung asing (FDI). Kenaikan investasi lainnya disebabkan antara lain oleh meningkatnya penarikan simpanan di luar negeri dan penarikan pinjaman luar negeri terkait meningkatnya realisasi proyek infrastruktur pemerintah. Sementara itu, kenaikan aliran masuk investasi langsung asing (FDI) terutama pada sektor pertambangan, keuangan, dan manufaktur sejalan dengan perbaikan investasi domestik.

Dengan perkembangan transaksi modal dan keuangan serta defisit transaksi berjalan, kinerja NPI pada triwulan IV 2015 mencatat surplus. NPI pada triwulan IV 2015 mengalami surplus sebesar 5,1 miliar dolar AS, lebih baik dibandingkan dengan defisit NPI pada triwulan III 2015 sebesar 4,6 miliar dolar AS. Surplus NPI triwulan IV 2015 tersebut pada gilirannya mendorong kenaikan posisi cadangan devisa dari US\$101,7 miliar pada akhir triwulan III 2015 menjadi US\$105,9 miliar pada akhir triwulan IV 2015. Jumlah cadangan devisa tersebut cukup untuk membiayai kebutuhan pembayaran impor dan utang luar negeri pemerintah selama 7,4 bulan dan berada di atas standar kecukupan internasional.

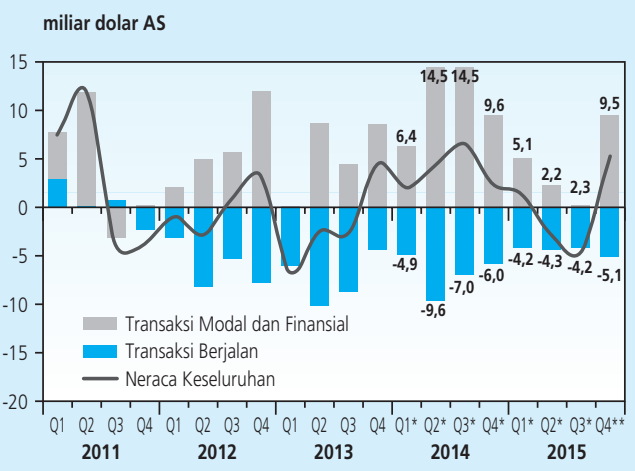

Grafik 9. Neraca Pembayaran Indonesia

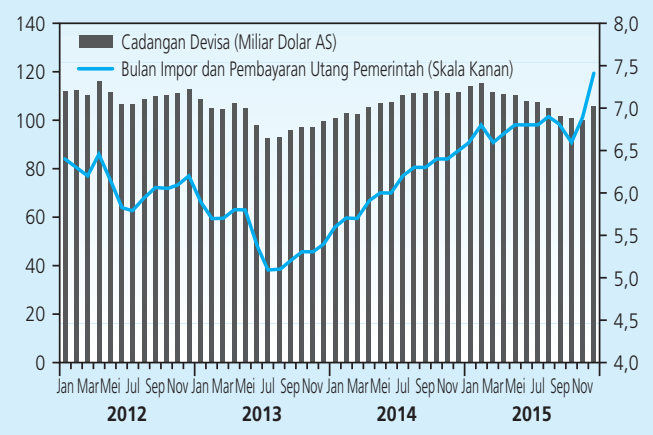

Grafik 10. Perkembangan Cadangan Devisa 


\subsection{Nilai Tukar Rupiah}

Selama triwulan IV 2015, nilai tukar rupiah menguat sebesar 6,27\%, secara point to point (ptp), dan mencapai level Rp13.785 per dolar AS. Dari sisi eksternal, penguatan rupiah selama terkait dengan meredanya ketidakpastian di pasar keuangan global, sejalan dengan hasil FOMC September 2015 yang sempat dovish, kenaikan FFR pada 17 Desember 2015 yang telah diantisipasi pasar dan pernyataan the Fed paska kenaikan FFR bahwa normalisasi akan dilakukan secara gradual dan terbatas. Di sisi domestik, membaiknya optimisme terhadap prospek ekonomi Indonesia, seiring dengan rangkaian paket kebijakan pemerintah dan paket stabilisasi nilai tukar yang dikeluarkan oleh Bank Indonesia, juga mendorong penguatan Rupiah. Faktor-faktor positif tersebut mendorong meningkatnya aliran modal masuk asing, khususnya ke pasar surat berharga negara, yang selanjutnya mendorong penguatan Rupiah.

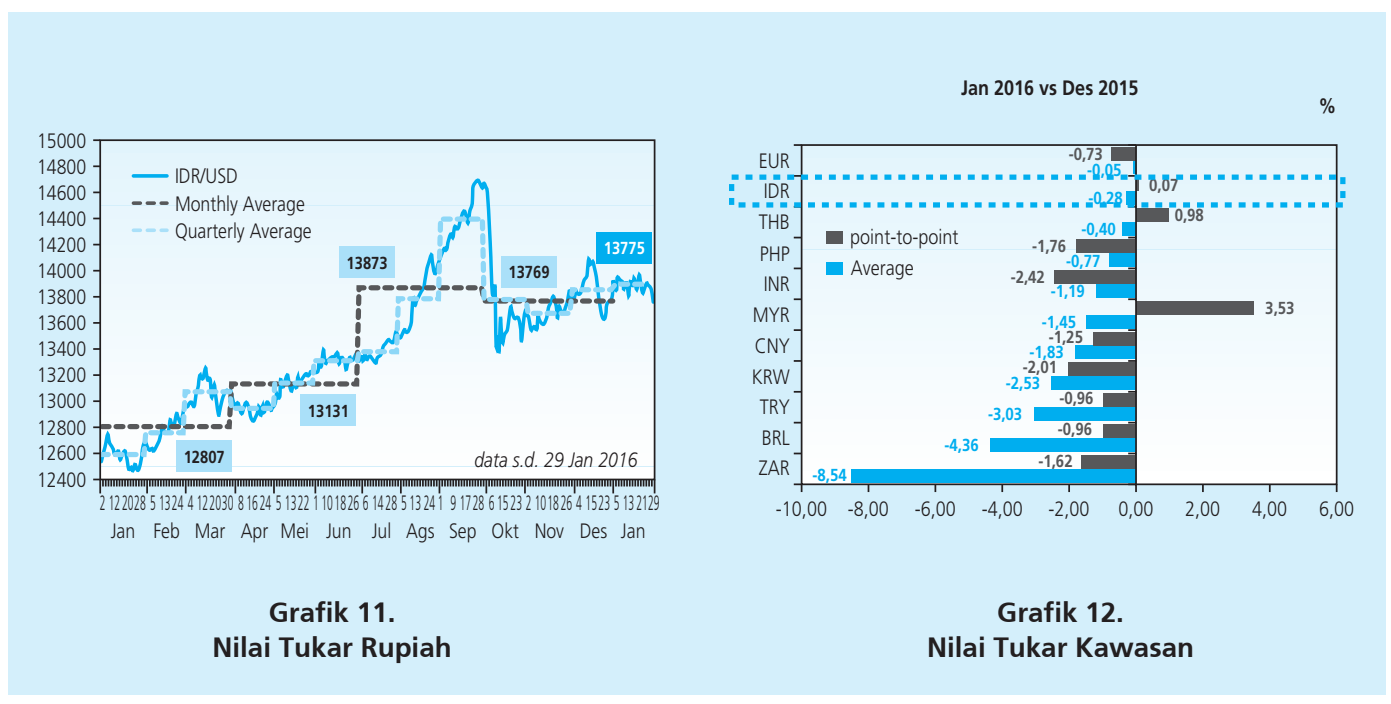

\subsection{Inflasi}

Inflasi IHK pada triwulan IV 2015 melambat dibandingkan triwulan sebelumnya. Inflasi IHK tercatat sebesar 1,08\% (qtq) atau 3,35\% (yoy), lebih rendah dibandingkan triwulan sebelumnya sebesar 1,27\% (qtq) atau 6,83\% (yoy) (Grafik 13). Lebih rendahnya inflasi tersebut terutama didorong oleh melambatnya inflasi inti. Melambatnya inflasi inti dibandingkan triwulan sebelumnya disebabkan oleh berlalunya faktor musiman (Lebaran dan tahun ajaran baru), rendahnya harga global, serta permintaan domestik yang masih lemah. Inflasi Volatile Food (VF) lebih tinggi dibandingkan triwulan sebelumnya, didorong oleh kenaikan harga hortikultura (aneka cabai dan bawang) akibat musim tanam yang sedang berlangsung. Inflasi Administered Prices (AP) tercatat meningkat dibandingkan triwulan sebelumnya, didorong oleh kenaikan berbagai tarif rokok. 
Inflasi inti pada triwulan IV 2015 terkendali didorong oleh permintaan domestik yang terbatas dan terjaganya ekspektasi inflasi. Inflasi inti triwulan IV 2015 tercatat sebesar 0,62\% (qtq) atau 3,95\% (yoy), lebih rendah dibandingkan triwulan sebelumnya sebesar 1,30\% (qtq) atau 5,07\% (yoy), didorong oleh berlalunya faktor musiman (Lebaran dan tahun ajaran baru), permintaan domestik yang masih lemah, dan apresiasi Rupiah yang berlangsung pada Oktober dan November. Selain itu, masih rendahnya harga global juga turut menyumbang pada terkendalinya inflasi inti. Inflasi inti yang terjaga pada triwulan IV 2015 turut didukung oleh ekspektasi inflasi yang terkendali baik di level pedagang eceran (Grafik 14) maupun konsumen.

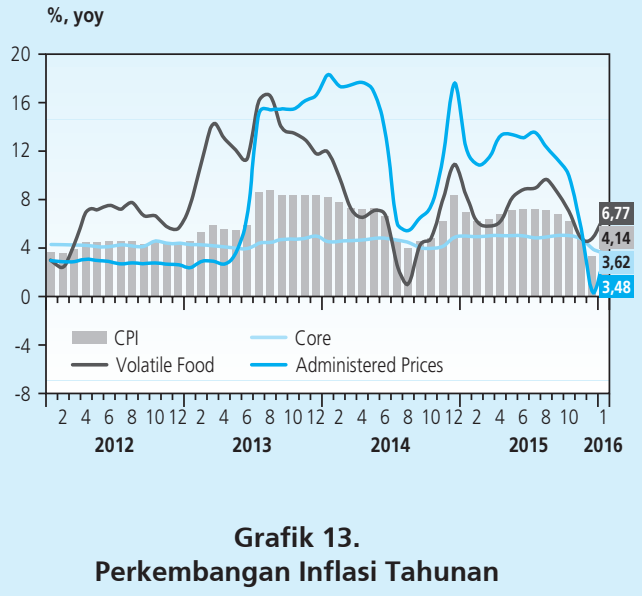

Kelompok volatile food triwulan IV 2015 tercatat mengalami inflasi sebesar 2,62\% (qtq) atau 4,84\% (yoy), lebih tinggi dibandingkan triwulan III 2015 sebesar 1,82\% (qtq) atau 8,52\% (yoy). Realisasi inflasi volatile food yang lebih tinggi terutama didorong oleh kenaikan harga hortikultura (aneka cabai dan bawang). Kenaikan harga hortikultura terutama didorong oleh pasokan yang terbatas akibat musim tanam yang sedang berlangsung.

Kelompok administered prices triwulan IV 2015 tercatat inflasi sebesar 1,09\% (qtq) atau 0,39\% (yoy), lebih tinggi dibandingkan triwulan III 2015 sebesar 0,80\% (qtq) atau 11,26\% (yoy). Inflasi kelompok administered prices terutama didorong oleh kenaikan harga aneka rokok sejalan dengan implementasi Peraturan Menteri Keuangan (PMK) Nomor 20 Tahun 2015 yang mewajibkan pembayaran pita cukai harus lunas pada Desember 2015.

Secara spasial, tekanan inflasi pada triwulan IV 2014 lebih rendah dibandingkan triwulan III 2015 (qtq) terutama ditopang oleh rendahnya inflasi wilayah Jawa. Sementara di Sumatera, Kalimantan dan KTI tekanan inflasi meningkat seiring dengan kenaikan harga beberapa 
komoditas pangan a.I aneka cabai, daging ayam ras, telur ayam ras dan beras. Rendahnya inflasi Jawa ditopang oleh fluktuasi harga bahan pangan yang lebih minim dibandingkan wilayah lainnya dan koreksi dari komoditas sandang, khususnya emas perhiasan. Adapun realisasi inflasi tertinggi terjadi NTT dan Sulawesi Tengah.

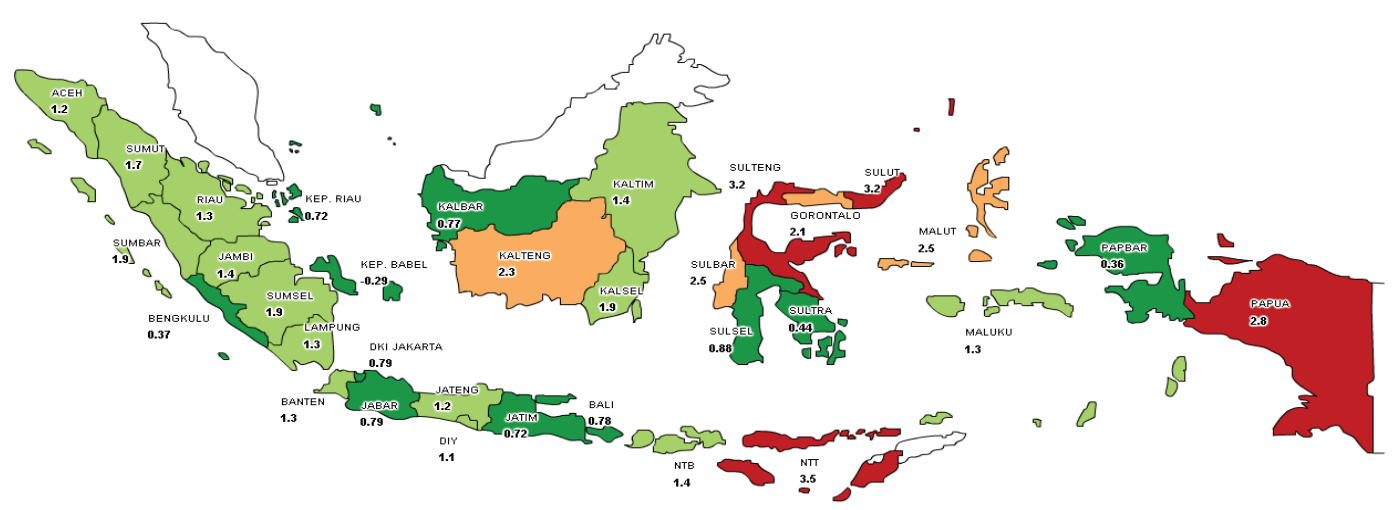

\begin{tabular}{ll|l|l|} 
Inf $\geq 2.5 \%$ & $2.5 \% \leq \inf <2.0 \%$ & $2.0 \% \leq \inf <1.0 \%$ & inf $<1.0 \%$
\end{tabular}

Gambar 2. Peta Inflasi daerah Triwulan IV 2015 (\%, qtq)

\section{PERKEMBANGAN MONETER, PERBANKAN, DAN SISTEM PEMBAYARAN}

\subsection{Moneter}

Likuiditas di Pasar Uang Antar Bank (PUAB) sedikit mengetat, namun secara umum tetap terjaga. Posisi DF turun dari Rp92,1 triliun pada triwulan III 2015 menjadi Rp79,2 triliun pada triwulan IV 2015. Rata-rata suku bunga PUAB O/N pada triwulan IV 2015 mengalami peningkatan dari 5,85\% (qtq) pada triwulan III 2015 menjadi 5,97\% (qtq) (Grafik 15). Peningkatan tersebut antara lain dipengaruhi kenaikan kebutuhan likuiditas pada Desember 2015. Namun demikian, likuiditas secara umum tetap terjaga, tercermin dari volume rata-rata PUAB total pada triwulan IV 2015 yang meningkat menjadi Rp12,39 triliun dari Rp10,85 triliun pada triwulan sebelumnya. Likuiditas pasar uang mulai berangsur pulih pada Januari 2016 sejalan dengan masuknya kembali uang kartal dalam sistem perbankan dan ekspansi fiskal.

Suku bunga deposito pada triwulan IV 2015 relatif stabil, sementara suku bunga kredit menurun pada triwulan IV 2015. Rata-rata tertimbang (RRT) suku bunga deposito pada triwulan IV 2015 stabil di 7,94\% (yoy) atau sama dengan RRT suku bunga deposito pada triwulan III 2015. Meskipun relatif stabil dibandingkan triwulan sebelumnya, RRT suku bunga deposito pada Desember (triwulan IV) 2015 naik sebesar 7 bps dari bulan sebelumnya. Kenaikan tersebut 
dipengaruhi oleh kondisi likuiditas perbankan yang relatif mengetat di Desember 2015 terutama akibat faktor musiman meningkatnya kebutuhan likuiditas untuk memenuhi kebutuhan Natal dan Tahun Baru, serta operasi fiskal yang lebih kontraktif. Sementara itu, RRT suku bunga kredit pada triwulan IV 2015 turun 8 bps menjadi 12,83\% (yoy) dari sebelumnya 12,91\% (yoy) pada triwulan III 2015 (Grafik 16). Penurunan terutama berasal dari suku bunga KMK dan KI yang masing-masing turun sebesar 12 bps dan 7 bps menjadi 12,46\% (yoy) dan 12,12\% (yoy). Dengan perkembangan tersebut, spread antara suku bunga kredit dan deposito menyempit menjadi 489 bps dari bulan sebelumnya 495 bps.

Likuiditas perekonomian (M2) pada triwulan IV 2015 tumbuh melambat dipengaruhi oleh penurunan uang kuasi. Pertumbuhan M2 pada triwulan IV mengalami perlambatan menjadi $8,95 \%$ (yoy) dibandingkan dengan triwulan sebelumnya 12,43\% (yoy). Perlambatan laju pertumbuhan M2 tersebut terjadi karena menurunnya pertumbuhan uang kuasi di triwulan IV 2015 tidak mampu dikompensasi oleh kenaikan pertumbuhan M1. Pertumbuhan uang kuasi menurun dari dari 12,53\% (yoy) pada triwulan III 2015 menjadi 8,37\% (yoy) pada triwulan IV 2015. Pertumbuhan M1 meningkat dari 8,51\% (yoy) pada triwulan III 2015 menjadi 11,59\% (yoy) pada triwulan IV 2015. Meningkatnya pertumbuhan M1 terutama dikontribusi oleh pertumbuhan giro rupiah milik swasta (korporasi dan perorangan). Pertumbuhan uang kartal ini mengindikasikan pertumbuhan ekonomi yang membaik dari triwulan sebelumnya.

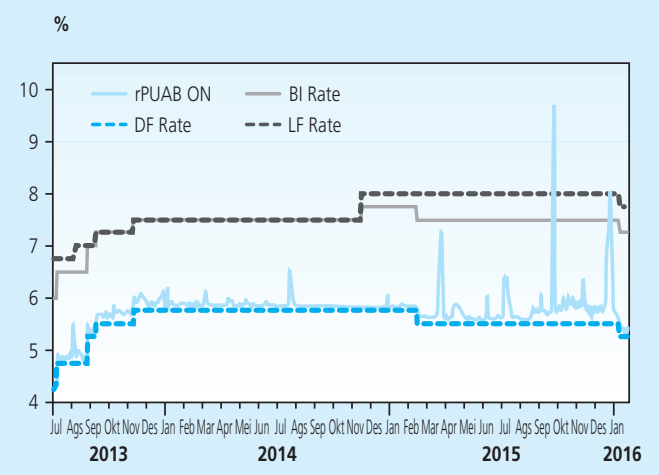

Grafik 15.

BI Rate, DF Rate dan Suku Bunga PUAB ON

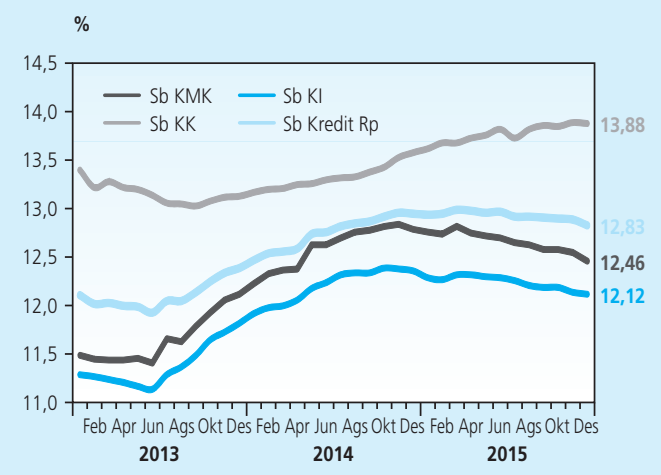

Grafik 16. Suku Bunga Kredit: KMK, KI dan KK

Berdasarkan faktor yang mempengaruhi, perlambatan M2 bersumber baik dari NFA maupun NDA. Penurunan NFA tersebut didorong oleh penurunan NFA BI. Sementara itu, perlambatan NDA didorong oleh melambatnya kredit dan NCG akibat meningkatnya simpanan pemerintah di BI dalam rangka prefunding APBN 2016. 


\subsection{Industri Perbankan}

Stabilitas sistem keuangan tetap solid ditopang oleh ketahanan sistem perbankan dan relatif terjaganya kinerja pasar keuangan. Ketahanan industri perbankan tetap kuat dengan risiko-risiko kredit, likuiditas dan pasar yang cukup terjaga, serta dukungan modal yang kuat.

Pertumbuhan kredit pada triwulan IV 2015 masih menunjukkan tren yang menurun. Pertumbuhan kredit ${ }^{2}$ pada triwulan IV 2015 tercatat menurun dari 11,1\% (yoy) pada triwulan III 2015 menjadi 10,45\% (yoy) (Grafik 17). Penurunan pertumbuhan kredit pada triwulan IV 2015 terutama berasal dari penurunan pertumbuhan KMK dari 10,72\% (yoy) pada triwulan III 2015 menjadi 9,04\% (yoy) pada triwulan IV. Sementara itu, pertumbuhan KI mengalami kenaikan menjadi 14,7\% (yoy) pada triwulan IV 2015 dari sebelumnya 12,95\% (yoy) pada triwulan III 2015. Namun, kenaikan pertumbuhan KI tersebut tidak mampu mendorong kenaikan pertumbuhan kredit total. Secara sektoral, peningkatan pertumbuhan kredit antara lain terjadi pada sektor listrik, air dan gas, sektor pengangkutan dan sektor jasa dunia usaha.

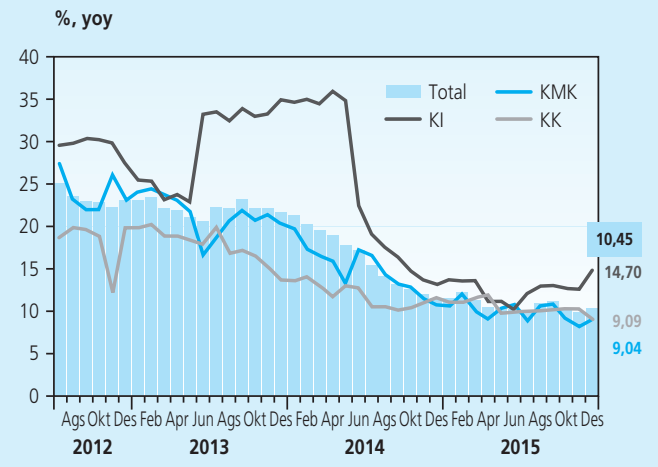

Grafik 17.

Pertumbuhan Kredit Menurut Jenis Penggunaan

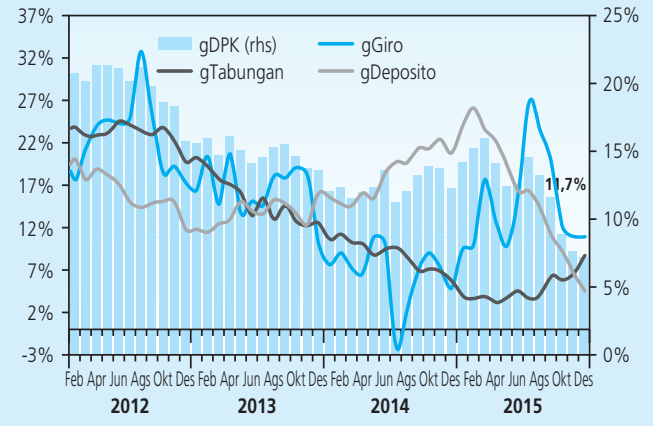

Grafik 18.

Pertumbuhan DPK

Pertumbuhan Dana Pihak Ketiga (DPK) pada triwulan IV 2015 menurun, terutama bersumber dari penurunan pertumbuhan deposito. Pertumbuhan DPK pada triwulan IV 2015 tercatat sebesar 7,3\% (yoy), lebih rendah dari triwulan sebelumnya sebesar 11,7\% (yoy) (Grafik 18). Penurunan DPK terutama bersumber dari pertumbuhan deposito yang turun dari $11,2 \%$ (yoy) pada triwulan III 2015 menjadi 5,0\% (yoy) pada triwulan IV 2015. Pertumbuhan giro juga mengalami perlambatan dari 13,7\% (yoy) pada triwulan III 2015 menjadi 10,3\% (yoy).

2 Kredit menurut konsep perbankan. 
Sementara itu, pertumbuhan tabungan Rupiah mengalami kenaikan pada triwulan IV 2015 menjadi 7,3\% (yoy) dari triwulan sebelumnya 4\% (yoy). Namun, kenaikan tersebut belum mampu mendorong pertumbuhan DPK.

Kondisi perbankan tetap terjaga di tengah tingginya risiko yang berpotensi menggangu stabilitas sistem keuangan. Pada triwulan IV 2015, ketahanan permodalan masih memadai dengan rasio kecukupan modal (Capital Adequacy Ratio/CAR) yang masih tinggi sebesar 21,2\%, jauh di atas ketentuan minimum 8\% (Tabel 2). Sementara itu, rasio kredit bermasalah (Non Performing Loan/NPL) tetap rendah dan stabil di kisaran 2,5\%. Sementara itu, dari sisi profitabilitas, Return on Assets (ROA) perbankan tercatat sebesar 2,3\%.

\begin{tabular}{|c|c|c|c|c|c|c|c|c|c|c|c|c|c|c|c|c|c|}
\hline \multicolumn{18}{|c|}{$\begin{array}{c}\text { Tabel } 2 \\
\text { Kondisi Umum Perbankan }\end{array}$} \\
\hline \multirow{2}{*}{ Indikator Utama } & & \multicolumn{4}{|c|}{2014} & \multicolumn{12}{|c|}{2015} \\
\hline & & Sep & Okt & Nov & Des & Jan & Feb & Mar & Apr & Mei & Jun & Jul & Ags & Sep & Okt & Nov & Des \\
\hline Total Aset & (T Rp) & $5,418.8$ & $5,445.7$ & $5,511.1$ & $5,615.1$ & $5,622.0$ & $5,683.2$ & $5,784.0$ & $5,792.7$ & $5,837.7$ & $5,933.2$ & $5,925.7$ & $6,010.7$ & $6,147.5$ & $5,997.3$ & $6,022.9$ & $6,132.8$ \\
\hline DPK & (T Rp) & $3,995.8$ & $4,011.4$ & $4,054.7$ & $4,114.4$ & $4,105.9$ & $4,151.4$ & $4,198.6$ & $4,217.6$ & $4,232.1$ & $4,319.7$ & $4,328.8$ & $4,366.6$ & $4,464.1$ & $4,370.4$ & $4,367.0$ & $4,413.2$ \\
\hline Kreditt & (T Rp) & $3,561.3$ & $3,558.1$ & $3,596.6$ & $3,674.3$ & $3,634.3$ & $3,665.7$ & $3,679.9$ & $3,711.6$ & $3,757.1$ & $3,828.0$ & $3,833.7$ & $3,881.3$ & $3,956.5$ & $3,923.4$ & $3,950.7$ & $4,058.1$ \\
\hline $\mathrm{LDR}^{*}$ & $(\%)$ & 89.13 & 88.70 & 88.70 & 89.30 & 88.52 & 88.30 & 87.65 & 88.00 & 88.78 & 88.62 & 88.56 & 88.9 & 88.6 & 89.8 & 90.5 & 92.0 \\
\hline NPLsBruto* & $(\%)$ & 2.29 & 2.35 & 2.36 & 2.16 & 2.35 & 2.43 & 2.40 & 2.48 & 2.58 & 2.56 & 2.70 & 2.8 & 2.7 & 2.7 & 2.7 & 2.5 \\
\hline CAR & $(\%)$ & 19.40 & 19.64 & 19.62 & 19.38 & 20.84 & 21.09 & 20.73 & 20.55 & 20.28 & 20.13 & 20.56 & 20.5 & 20.4 & 20.8 & 21.1 & 21.2 \\
\hline NIM & $(\%)$ & 4.2 & 4.2 & 4.2 & 4.1 & 4.1 & 4.0 & 5.1 & 5.2 & 5.2 & 5.2 & 5.2 & 5.2 & 5.2 & 5.2 & 5.2 & 5.2 \\
\hline ROA & $(\%)$ & 2.8 & 28 & 2.8 & 2.8 & 2.7 & 2.4 & 2.6 & 2.5 & 2.4 & 2.2 & 2.2 & 2.2 & 2.2 & 2.2 & 2.3 & 2.3 \\
\hline
\end{tabular}

\subsection{Pasar Saham dan Pasar Surat Berharga Negara}

Perkembangan pasar saham domestik pada triwulan IV 2015 menunjukkan kinerja yang meningkat. IHSG pada triwulan IV 2015 mengalami peningkatan sebesar 8,7\% (qtq) menjadi 4.593,01 (31 Desember 2015) (Grafik 19). Peningkatan kinerja pasar saham dipengaruhi oleh sentimen eksternal dan domestik. Dari sisi eksternal, risiko di pasar keuangan global yang bersumber dari kemungkinan kenaikan suku bunga FFR semakin mereda. Di sisi domestik, peningkatan kinerja pasar saham didorong oleh sentimen positif terkait, antara lain, dengan terjaganya inflasi dan membaiknya optimisme terhadap prospek ekonomi, seiring dengan rangkaian paket kebijakan pemerintah dan paket stabilisasi nilai tukar yang dikeluarkan BI. Kinerja saham pada triwulan IV 2015 lebih baik dari kinerja pasar saham negara ASEAN, Hongkong dan India.

Kinerja pasar SBN pada triwulan IV 2015 mengalami peningkatan, tercermin dari penurunan yield SBN untuk seluruh tenor. Sejalan dengan pasar saham, perbaikan kinerja pasar SBN juga dipengaruhi oleh sentimen positif yang bersumber dari eksternal dan domestik. Secara keseluruhan, yield SBN turun sebesar 73 bps dari 9,55\% menjadi 8,82\%. Adapun yield 
jangka pendek, menengah dan panjang masing-masing turun sebesar 66 bps, 71 bps dan 84 bps menjadi 8,54\%, 8,88\% dan 9,09\%. Sementara itu, yield benchmark 10 tahun turun sebesar 84 bps dari 9,60\% menjadi 8,76\% (Grafik 1.49). Pada triwulan IV 2015, investor asing mencatat net beli sebesar Rp34,1 triliun sehingga kepemilikan asing pada triwulan IV 2015 tercatat sebesar 36,54\% (Grafik 20).

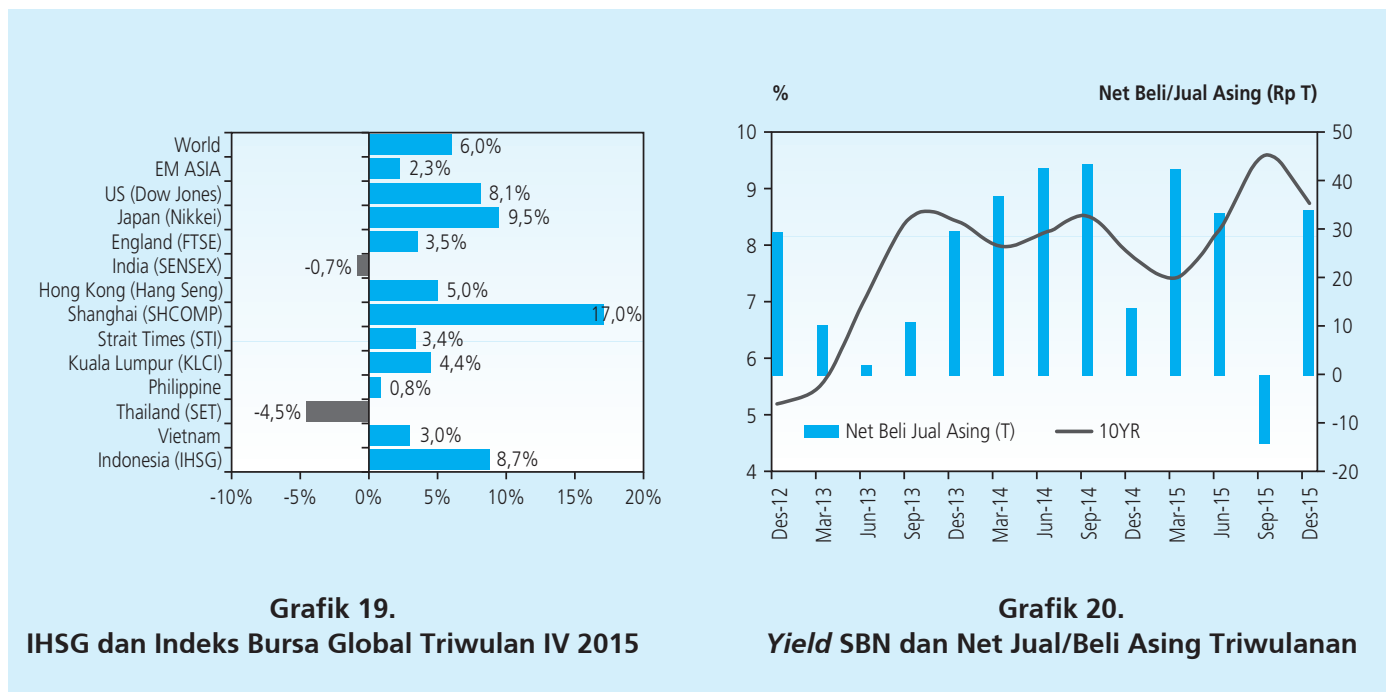

\subsection{Pembiayaan Non Bank}

Pembiayaan ekonomi nonbank meningkat. Total pembiayaan selama triwulan IV 2015 melalui penerbitan saham perdana, right issue, obligasi korporasi, medium term notes, promissory notes dan lembaga keuangan lainnya meningkat menjadi Rp41,6 triliun, lebih tinggi dibandingkan triwulan III 2015 sebesar Rp17,6 triliun (Tabel 3). Peningkatan terutama disumbang oleh naiknya penerbitan saham menjadi Rp29,1 triliun dari Rp5,3 triliun pada triwulan sebelumnya.

Rp Trillion

\begin{tabular}{|c|c|c|c|c|c|c|c|c|c|c|}
\hline \multicolumn{11}{|c|}{$\begin{array}{c}\text { Table } 3 \\
\text { Pembiayaan Non Bank }\end{array}$} \\
\hline & \multicolumn{5}{|c|}{2014} & \multicolumn{5}{|c|}{2015} \\
\hline & Tw I & Tw II & Tw III & Tw IV & Total & Tw I & Tw II & Tw III & Tw IV & Total \\
\hline Nonbank & 18.2 & 39.2 & 8.2 & 44.5 & 110.0 & 22.3 & 47.7 & 17.6 & 41.6 & 129.2 \\
\hline Saham & 8.6 & 17.7 & 0.0 & 21.2 & 47.6 & 4.7 & 14.5 & 5.3 & 29.1 & 53.6 \\
\hline o/w Emiten Sektor Keuangan & 5.5 & 4.1 & 0.0 & 3.1 & 12.8 & 0.0 & 0.0 & 0.1 & 0.0 & 0.1 \\
\hline Obligasi & 8.0 & 17.5 & 6.8 & 15.1 & 47.5 & 12.8 & 26.2 & 9.5 & 7.0 & 55.5 \\
\hline o/w Emiten Sektor Keuangan & 5.5 & 9.5 & 5.5 & 9.8 & 30.3 & 12.1 & 9.9 & 7.5 & 5.7 & 35.2 \\
\hline MTN dan Promissory Notes + NCD & 1.6 & 3.8 & 1.4 & 8.1 & 14.9 & 4.8 & 7.0 & 2.9 & 5.6 & 20.3 \\
\hline o/w Emiten Sektor Keuangan & 1.2 & 3.2 & 1.2 & 3.5 & 9.2 & 3.3 & 6.2 & 1.2 & 3.4 & 14.1 \\
\hline
\end{tabular}




\subsection{Perkembangan Sistem Pembayaran}

Perkembangan pengelolaan uang rupiah secara umum sejalan dengan perkembangan ekonomi domestik, khususnya dari sektor konsumsi rumah tangga. Rata-rata harian Uang Kartal yang Diedarkan (UYD) pada triwulan IV 2015 adalah sebesar Rp586,8 triliun atau tumbuh $11,0 \%$ (yoy), meningkat dibandingkan dengan triwulan sebelumnya sebesar Rp518.3 triliun $(9,4 \%$, yoy) (Grafik 21$)$. Peningkatan pertumbuhan UYD tersebut ditopang oleh meningkatnya aktivitas ekonomi pada triwulan IV 2015, termasuk tingginya penarikan uang kartal pada bulan Desember 2015 yang bertepatan dengan periode Natal dan liburan akhir tahun 2015.

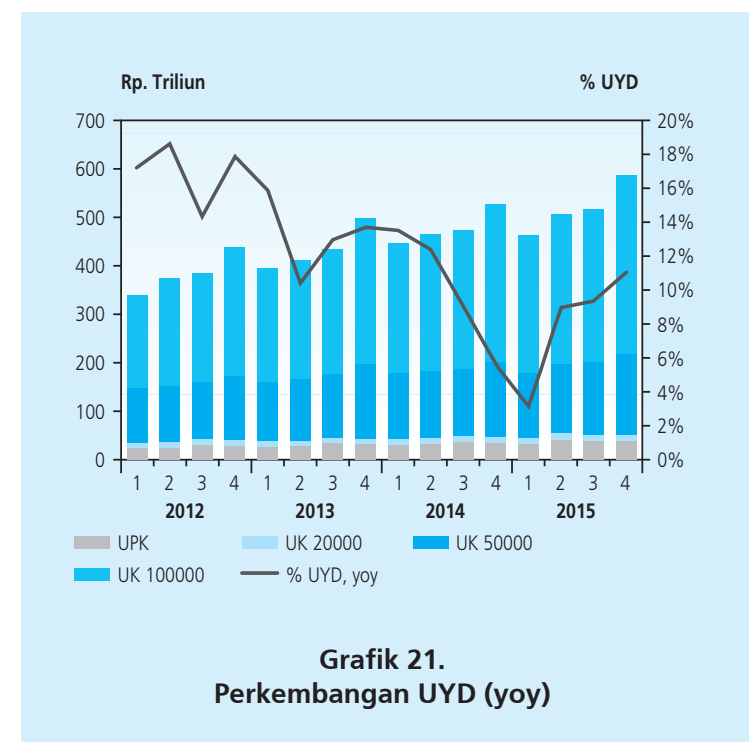

Di tengah tren pertumbuhan UYD tersebut, Bank Indonesia terus berupaya meningkatkan kualitas uang yang beredar. Selama triwulan IV 2015, sejumlah 1,7 miliar lembar Uang Tidak Layak Edar (UTLE) senilai Rp44,0 triliun telah dimusnahkan dan diganti dengan uang rupiah yang layak edar. Jumlah pemusnahan UTLE tersebut lebih tinggi dibandingkan dengan triwulan III 2015 yang tercatat sebesar 1,5 miliar lembar atau senilai Rp41,9 triliun. Tingginya pemusnahan pada triwulan laporan sejalan dengan meningkatnya aliran uang masuk (inflow) dari perbankan ke Bank Indonesia dan peningkatkan standar kualitas uang yang beredar (fitness level).

Penyelenggaraan sistem pembayaran selama triwulan IV 2015 berjalan aman, lancar, dan terpelihara dengan baik. Dibandingkan dengan triwulan sebelumnya, transaksi sistem pembayaran nontunai pada triwulan IV 2015 mengalami peningkatan baik dari sisi nilai maupun volume transaksi. Peningkatan volume transaksi tercatat sebesar 29.354,23 transaksi atau meningkat sebesar 2,06\% (qtq). Sejalan dengan hal itu, nilai transaksi mengalami peningkatan sebesar Rp2.661,81 triliun atau meningkat sebesar 6,98\% (qtq) (Tabel 4). Secara 
umum, volume transaksi sistem pembayaran masih didominasi oleh transaksi Alat pembayaran dengan Menggunakan Kartu (APMK) yang mencapai 1,3 triliun transaksi atau tumbuh 4,9\% (qtq). Peningkatan volume transaksi APMK mencerminkan semakin meningkat dan meluasnya penggunaan instrumen pembayaran nontunai oleh masyarakat. Namun, peningkatan volume transaksi terbesar pada triwulan IV 2015 terjadi pada transaksi BI-SSSS sebesar 30,5\% (qtq) atau 12,1 ribu transaksi. Berdasarkan nilainya, peningkatan nilai transaksi pada triwulan IV 2015 terutama didorong oleh meningkatnya nilai transaksi Bank Indonesia-Scripless Securities Settlement System (BI-SSSS) dan transaksi Sistem Kliring Nasional Bank Indonesia (SKNBI). Nilai transaksi BI-SSSS meningkat sebesar Rp2.677,4 triliun atau naik 33,4\% (qtq) dan transaksi SKNBI meningkat Rp221,5 triliun atau naik 30,0\% (qtq).

Volume (Ribu)

Table 4

Perkembangan Volume Sistem Pembayaran Non Tunai

\begin{tabular}{l|r|r|r|r|r}
\multirow{2}{*}{\begin{tabular}{c} 
Transaksi Sistem Pembayaran Non \\
\multirow{2}{*}{ BI-RTGS }
\end{tabular}} & \multicolumn{5}{|c}{$\mathbf{2 0 1 5}$} \\
\cline { 2 - 6 } & Q I & Q II & Q III & Q IV & QtQ (III to IV) \\
\hline BI-SSSS & $2,814.82$ & $2,917.79$ & $2,939.05$ & $2,371.24$ & $-19.32 \%$ \\
\hline Kliring & 45.60 & 46.36 & 39.78 & 51.91 & $30.51 \%$ \\
\hline APMK & $27,120.50$ & $27,868.97$ & $27,855.16$ & $30,688.25$ & $10.17 \%$ \\
\hline Kartu Kredit & $1,142,496.20$ & $1,203,569.01$ & $1,224,670.52$ & $1,284.98$ & $4.92 \%$ \\
\hline Kartu ATM dan ATM/Debet & $65,662.44$ & $70,286.39$ & $71,179.69$ & $74,197.00$ & $4.24 \%$ \\
\hline Uang Elektronik & $1,076,833.76$ & $1,133,282.61$ & $1,153,490.84$ & $1,210,780.00$ & $4.97 \%$ \\
\hline Total & $80,265.97$ & $143,092.96$ & $172,725.50$ & $139,495.00$ & $-19.24 \%$ \\
\hline
\end{tabular}

Di tengah peningkatan nilai dan volume transaksi sistem pembayaran nontunai pada triwulan IV 2015, transaksi pembayaran yang diselesaikan melalui Sistem BI-RTGS justru mengalami penurunan baik dari sisi nilai maupun volume. Secara umum, penurunan yang terjadi pada transaksi melalui Sistem BI-RTGS antara lain disebabkan adanya kebijakan peningkatan batas minimal nilai transaksi melalui Sistem BI-RTGS menjadi di atas Rp500 juta. Volume transaksi sistem pembayaran yang diselesaikan melalui Sistem BI-RTGS tercatat menurun sebesar 19,32\% menjadi 2.371,24 ribu transaksi. Penurunan tersebut diikuti dengan penurunan nilai transaksi sebesar 1,02\% menjadi Rp27.736,73 triliun pada triwulan IV 2015.

\section{PROSPEK PEREKONOMIAN}

Bank Indonesia memperkirakan pertumbuhan ekonomi pada tahun 2016 lebih tinggi dari tahun 2015 yaitu pada kisaran 5,2 - 5,6\%. Pertumbuhan ekonomi tersebut diperkirakan akan ditopang oleh stimulus fiskal, khususnya realisasi pembangunan proyek infrastruktur yang semakin cepat. Investasi swasta diharapkan akan meningkat seiring dengan dampak paket 
kebijakan pemerintah dan pemanfaatan ruang pelonggaran moneter secara terukur dengan tetap menjaga stabilitas makro. Sementara itu, kontribusi net ekspor masih negatif dipengaruhi kondisi eksternal yg belum pulih dan impor yang mulai meningkat untuk mendukung realisasi proyek infrastruktur.

Dalam periode yang sama, inflasi diperkirakan akan berada di sekitar titik tengah kisaran sasaran inflasi $4 \pm 1 \%$. Tekanan inflasi dari sisi permintaan diprakirakan meningkat seiring meningkatnya utilisasi kapasitas produksi. Ekspektasi inflasi diperkirakan juga tetap terjaga, didukung oleh kebijakan dan koordinasi antara Bank Indonesia dan Pemerintah. Sementara itu, tekanan inflasi dari sisi eksternal diprakirakan minimal sejalan dengan terbatasnya peningkatan harga-harga komoditas internasional, tren penurunan harga minyak dan nilai tukar yang lebih stabil.

Bank Indonesia akan terus mencermati beberapa risiko yang membayangi proses penyesuaian ekonomi ke depan. Dari sisi global, risiko tersebut antara lain berkaitan dengan belum solidnya pertumbuhan ekonomi dunia, terus menurunnya harga komoditas termasuk harga minyak, serta perlambatan ekonomi dan pasar keuangan Tiongkok. Dari sisi domestik, risiko yang perlu mendapat perhatian adalah potensi tekanan inflasi volatile food. 
250 Bulletin of Monetary, Economics and Banking, Volume 18, Number 3, January 2016

Halaman ini sengaja dikosongkan 